\title{
Better Quality of Sleep among Adolescents by Considering the Intensity of Social Media Utilization
}

\author{
Siti Habibah' ${ }^{1}$, Karina Megasari Winahyu' ${ }^{1}$, Hyang Wreksagung ${ }^{2}$, Hera Hastuti ${ }^{1}$, Kartini \\ Kartini ${ }^{1}$
}

1 Universitas Muhammadiyah Tangerang

2 Tangerang District Hospital, Tangerang

\section{Article Info}

Article History:

Submitted: Dec $3^{\text {rd }}, 2020$

Accepted: Jan 22 ${ }^{\text {nd }}, 2021$

Published: Feb 13 ${ }^{\text {th }}, 2021$

Keywords:

Adolescents; Social Media Intensity; Quality of Sleep

\section{PENDAHULUAN}

Remaja merupakan kelompok usia dengan jumlah yang cukup besar di dunia maupun di Indonesia. Di Indonesia, pada tahun 2016 penduduk remaja berusia 10-24 tahun berjumlah 66,3 juta jiwa dari total penduduk sebesar 258,7 juta, sehingga satu di antara empat penduduk adalah remaja [1]. Menurut National Sleep Foundation (2018), remaja adalah populasi yang beresiko tinggi mengalami masalah tidur [2]. Berdasarkan penelitian yang dilakukan

\begin{abstract}
The basic human needs, such as sleep quality, often take for granted that low sleep quality among adolescents could affect various health problems. One of the factors correlated with sleep quality in adolescents is the use of social media. This study aimed to identify the association between social media utilization and sleep quality among adolescents. The study used a descriptive correlation with a cross-sectional design. The Social Networking Time Use Scale and Pittsburgh Sleep Quality Index questionnaires were used based upon validity and reliability test. A Cross-sectional study was used with a convenience sampling frame by recruiting 188 adolescents. The analysis technique used was Chi-Square. The results showed that respondents with a high intensity of social media users who have good sleep quality were $29(15,4 \%)$ respondents, and those who have low sleep quality were $66(35.1 \%)$ respondents. It revealed a significant association between the intensity of social media use and sleep quality in adolescents $(\mathrm{X} 2=27.564, \mathrm{df}=1, \mathrm{p}<0.05)$. It suggests that adolescents should reduce the intensity of social media use to improve their sleep quality.
\end{abstract}

oleh Short, Gradisar menunjukkan bahwa 23,1\% remaja di Australia Selatan memiliki masalah tidur. Di Indonesia sendiri berdasarkan penelitian yang dilakukan oleh Nafiah didapatkan bahwa $54.7 \%$ remaja mengalami masalah tidur. Hal ini menunjukan bahwa kualitas tidur merupakan masalah penting dalam menentukan kesehatan agregat remaja.

Tidur merupakan salah satu kebutuhan dasar manusia dan mempengaruhi kesehatan fisik dan mental manusia. Waktu

\footnotetext{
Corresponding author:

Karina Megasari Winahyu

karinawinahyu@yahoo.com

Media Keperawatan Indonesia, Vol 4 No 1, February 2021

e-ISSN: 2615-1669

ISSN: 2722-2802

DOI: $\underline{10.26714 / \mathrm{mki} .4 .1 .2021 .29-35}$
} 
tidur yang disarankan bagi remaja adalah 810 jam per hari [2]. Menariknya, Center for Disease Control and Prevention (CDC) menyatakan remaja usia 13-18 tahun yang tidur $<8$ jam dalam rentang 24 jam sudah termasuk insufisiensi waktu tidur. Akan tetapi, kebutuhan waktu tidur dapat ditentukan juga oleh usia, genetik atau aktivitas terkait lainnya [6]. Namun, pada kenyataannya banyak remaja yang memiliki waktu tidur yang kurang terpenuhi setiap harinya. Hal tersebut dapat menyebabkan penurunan kualitas tidur pada remaja [7].

Kualitas tidur pada remaja masih perlu dikaji lebih dalam karena beberapa penelitian sebelumnya mengidikasikan buruknya kualitas tidur remaja. Hasil literature review internasional menunjukkan, kelompok usia remaja dan dewasa muda rentan mengalami gangguan pada waktu tidur sehingga melaporkan kualitas tidur yang rendah dan berisiko buruk untuk kesehatan jangka panjang [8]. Hal ini senada dengan beberapa hasil penelitian di Indonesia, seperti studi Punkasaningtiyas dan Lombogia, Kairupan menunjukkan bahwa hanya sepertiga jumlah remaja (29.2 - $37.6 \%)$ yang melaporkan memilki kualitas tidur yang baik. Penelitian tersebut mengkonfirmasi hasil studi sebelumnya yang menunjukkan bahwa $69.3 \%$ remaja memiliki kualitas tidur yang rendah [11]. Hal ini menunjukkan bahwa sebagian besar remaja mengalami ketidakpuasan tidur.

Jika tidak diidentifikasi dan ditangani, maka kualitas tidur yang buruk dapat mengganggu tumbuh kembang remaja hingga masa dewasa awal mereka [8]. Selain itu, dampak negatif ketidakpuasan tidur, yaitu menurunkan kemampuan akademik [12], meningkatkan risiko masalah berat badan, gangguan psikologi seperti cemas bahkan depresi [13]. Oleh karena itu, perlu diidentifikasi faktor yang berkaitan dengan kualitas tidur, misalnya faktor penggunaan media sosial oleh remaja $[14,15]$.
Remaja saat ini merupakan populasi dengan tingkat ketergantungan tertinggi pada media sosial di seluruh dunia. Para remaja menghabiskan 1-3 jam per hari untuk menggunakan media sosial [16]. Beberapa penelitian terdahulu menemukan hubungan antara penggunaan media sosial dan kualitas tidur pada remaja. Hasil studi Punkasaningtiyas menunjukkan adanya hubungan signifikan antara media sosial dan kualitas tidur yang dirasakan oleh remaja, dimana sebagian besar remaja memiliki intensitas penggunaan media sosial yang tinggi cenderung memiliki kualitas tidur rendah. Sejalan dengan hal tersebut, remaja yang menggunakan media sosial secara rutin cenderung melaporkan insufisiensi jumlah tidur [17].

Namun, beberapa studi baik di Indonesia maupun studi internasional terdahulu mengenai hubungan antara penggunaan media sosial dan kualitas tidur pada remaja masih ditemukan inkonsistensi hasil. Misalnya, Aulia menyatakan bahwa tidak ada hubungan bermakna antara penggunaan media sosial dan kualitas tidur. Sama halnya dengan temuan Kaimal, Sajja yang menunjukkan bahwa penggunaan media sosial seperti Facebook, Instagram, dan Twitter sebelum waktu tidur tidak berpengaruh terhadap kualitas tidur. Hal tersebut mengindikasikan bahwa pengetahuan tentang hubungan antara intensitas media sosial dan kualitas tidur masih perlu diteliti lebih dalam.

Berdasarkan studi pendahuluan yang dilakukan pada siswa-siswi kelas XI dan beberapa guru di MAN 4 Tangerang menunjukkan bahwa hampir seluruh siswa-siswi kelas XI MAN 4 Tangerang adalah pengguna media sosial dan selalu menggunakannya setiap hari. Hasil wawancara yang dilakukan pada orang tua siswa, terungkap bahwa anak remajanya hampir setiap hari tidur larut malam hanya untuk mengakses media sosial sebelum tidur. Dampak yang ditimbulkan akibat penggunaan media sosial hingga larut 
malam tersebut membuat anak remaja lebih susah dibangunkan pada pagi hari.

Oleh karena itu, signifikansi dari dampak yang ditimbulkan akibat masif nya penggunaan media sosial, tingginya prevalensi kualitas tidur yang buruk pada remaja dan kesenjangan pada penelitian terdahulu (gaps of knowledge), seperti inkonsistensi hasil penelitian sebelumnya, dan studi pendahuluan, maka, penelitian ini bertujuan untuk mengetahui hubungan antara intensitas pemanfaatan media sosial dan kualitas tidur pada remaja.

\section{METODE}

Penelitian ini menggunakan desain penelitian deskriptif kuantitatif asosiatif. Penelitian ini menganalisis hubungan antara intensitas pemanfaatan media sosial dan kualitas tidur pada remaja. Pendekatan yang diguankan pada penelitian ini adalah cross-sectional. Penelitian ini dilakukan di MAN 4 Tangerang.

Subjek penelitian ini adalah siswa/i kelas XI tingkat Sekolah Menengah Atas. Jumlah responden penelitian adalah 188 orang. Tehnik sampling yang digunakan adalah Accidental Sampling.

Instrumen yang digunakan untuk mengukur intensitas penggunaan media sosial yaitu kuesioner Social Networking Time Use Scale (SONTUS) yang dibuat oleh Olufadi . Nilai reliabilitas kuesioner SONTUS pada penelitian ini yaitu 0,852 . Sedangkan instrumen yang digunakan untuk mengukur kualitas tidur adalah kuesioner Pittsburgh Sleep Quality Index (PSQI) yang dibuat oleh Buysse, Reynolds . Nilai reliabilitas kuesioner PSQI pada penelitian ini yaitu 0,892 . Kedua instrumen penelitian telah mendapatkan izin dari pengembang aslinya, kemudian diterjemahkan secara forward translation sebelum dilakukan uji validitas dan reliabilitas

Teknik analisis data terdiri dari analisis univariat dan bivariat. Analisis univariat menjelaskan distribusi frekuensi dari setiap variabel. Sedangkan analisis bivariat diukur menggunakan uji statistik Chi Square untuk mengidentifikasi hubungan antara intensitas penggunaan media sosial dengan kualitas tidur pada remaja di MAN 4 Tangerang. Penelitian ini telah lolos persetujuan etik dengan surat No: 013/ PE/ KE/ FKK-UMJ/ V/ 2019.

\section{HASIL}

Penelitian ini dilakukan kepada remaja di MAN 4 Tangerang. Penelitian dilakukan pada semua tingkat dengan jumlah responden sebanyak 188 siswa. Karakteristik remaja yang dilakukan pengukuran meliputi: jenis kelamin dan usia.

Hasil penelitian menunjukkan bahwa mayoritas responden berjenis kelamin perempuan dengan rata-rata usia responden adalah 16 tahun.

Tabel 1

Karakteristik Remaja di MAN 4 Tangerang ( $\mathrm{N}=188$ )

\begin{tabular}{lcc}
\hline \multicolumn{1}{c}{ Indikator } & $\mathrm{f}$ & $\%$ \\
\hline Jenis Kelamin & & \\
$\quad$ Laki-laki & 65 & 34,6 \\
Perempuan & 123 & 65,4 \\
\hline Umur (tahun) & & \\
16 & 113 & 60,1 \\
17 & 67 & 35,6 \\
18 & 8 & 4,3 \\
\hline Jumlah akun media sosial & & \\
$\quad \leq 2$ akun & 21 & 11,2 \\
$>2$ akun & 167 & 88,8 \\
\hline
\end{tabular}

Jenis Media Sosial yang

Digunakan

$\begin{array}{lll}\text { Facebook } & 95 & 50,5\end{array}$

Whatsapp $76 \quad 40,4$

Instagram $\quad 17 \quad 9,1$

Intensitas Penggunaan Media

Sosial

\begin{tabular}{lcc} 
Rendah & 93 & 49,5 \\
Tinggi & 95 & 50,5 \\
\hline Kualitas Tidur & & \\
Baik & 93 & 49,5 \\
Buruk & 95 & 50,5 \\
\hline
\end{tabular}

Hasil penelitian menunjukkan bahwa terdapat hubungan yang signifikan antara penggunaan social media dengan kualitas 
tidur remaja $(\mathrm{p}<0,05)$ dengan nilai koefisien 27,564. Berdasarkan nilai Odd Ratio dapat diprediksi bahwa pada populasi remaja yang menggunakan media sosial dengan intensitas rendah 5 kali lipat lebih baik kualitas tidurnya dibandingkan intensitas penggunaan media sosial tinggi $(\mathrm{OR}=5.02)$.

Tabel 2

Hubungan antara Intensitas Penggunaan Media Sosial dan Kualitas Tidur (N=188)

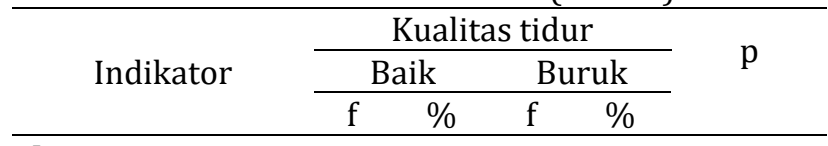

Intensitas

Penggunaan

Media Sosial

Rendah

$\begin{array}{llll}64 & 34,0 & 29 & 15,4\end{array}$

Tinggi

$29 \quad 15,4 \quad 66 \quad 35,1$

$0,0001^{*}$

* Chi-Square test

\section{PEMBAHASAN}

Hasil penelitian ini menunjukkan bahwa dari 188 responden, penggunaan media sosial dengan intensitas tinggi lebih mendominasi pada remaja, yaitu sebanyak 95 responden (50,5 \%). Sedangkan responden dengan intensitas penggunaan media sosial yang rendah sebanyak 93 responden (49,5\%). Hal ini sejalan dengan penelitian yang dilakukan oleh Candra melaporkan sebagian responden remaja menggunakan media sosial dengan intens $(50,2 \%)$. Selain itu, penelitian yang lain juga menunjukkan hal yang sama, seperti dalam penelitian Dewi [23] dari 134 responden, mayoritas melaoprkan intensitas yang tinggi dalam mengkases media sosialnya $(69,4 \%)$. Banyaknya jumlah remaja yang sering mengakses media sosianya dapat mengindikasikan kaitannya dengan aspek psikologis. Hal tersebut dikarenakan intensitas aktivitas seseorang memiliki keterkaitan yang erat dengan perasaannya, yaitu rasa senang dengan kegiatan tersebut sehingga berulang kali mendorong orang yang bersangkutan untuk melakukan kegiatan tersebut [24].

Karakteristik lain yang ditemukan pada penelitian ini, yaitu mayoritas responden remaja adalah perempuan $(65,4 \%)$.
Karakteristik yang sama ditunjukkan pada penelitian sebelumnya yang dilakukan oleh Punkasaningtiyas , remaja perempuan yang lebih mendominasi penggunaan media sosial (55,1\%). Studi kualitatif menunjukkan bahwa remaja perempuan cenderung memiliki literasi media yang tinggi; mereka berupaya meminimalisir akses penggunaan media tersebut karena sadar bahwa perhatian akan penampilan dan membandingkan dengan kehidupan sosial orang lain terlalu intens dapat membawa dampak negatif [25]. Hal ini dapat disebabkan oleh kecenderungan perempuan untuk peduli terhadap tampilan dan mengakses informasi, dimana media sosial banyak menampilkan diri seseorang (remaja dan teman sebayanya) melalui foto yang diunggah di akun seperti Facebook, Instagram atau story Whatsapp.

Remaja pada penelitian diketahui memiliki kecenderungan kualitas tidur buruk (50.5 $\%)$. Hal ini sesuai dengan hasil beberapa penelitian terdahulu dimana lebih dari sebagian responden melaporkan kualitas tidur yang buruk [9] [10] atau dikategorikan kurang terpenuhinya tidur yang berkualitas [7]. Kualitas tidur dapat dinilai dari berbagai komponen, antara lain durasi tidur, gangguan tidur, latensi tidur, efisiensi tidur, penggunaan obat tidur, dan disfungsi pada siang hari. Remaja membutuhkan waktu tidur 8-10 jam per hari. Jika satu atau lebih aspek di atas terganggu, kualitas tidur dapat terpengaruh [21].

Temuan penting lain yang ditunjukkan pada penelitian ini, yaitu mayoritas responden memiliki intensitas penggunaan media sosial yang tinggi dengan kualitas tidur yang buruk sebanyak 66 responden $(35,1 \%)$. Penelitian ini mendukung hasil penelitian Punkasaningtiyas bahwa terdapat hubungan antara penggunaan media sosial dengan kualitas tidur pada remaja. Penggunaan media sosial dengan intensitas yang lebih tinggi akan menyebabkan kualitas tidur yang buruk, terbukti dari mayoritas responden yang menggunakan 
media sosial dengan intensitas tinggi memiliki kualitas tidur yang buruk. Sebaliknya, responden yang memiliki intensitas rendah dalam menggunakan media sosial sebagian besar memiliki kualitas tidur yang baik. Hasil ini sejalan dengan studi Woods and Scott, di mana hasil menunjukkan bahwa penggunaan media sosial sangat terkait dengan kualitas tidur yang buruk. Dalam penelitian tersebut, ditemukan bahwa penggunaan media sosial pada malam hari lebih berhubungan erat dengan kurangnya kualitas tidur. Penggunaan media sosial saat akan tidur dapat mengganggu produksi melatonin melalui paparan cahaya digital menjelang tidur, dan notifikasi dari media sosial akan mengganggu proses tidur remaja.

Studi sebelumnya menunjukkan kesamaan dalam penggunaan media sosial pada saat menjelang tidur; Bedanya, penelitian ini lebih jauh menjelaskan bagaimana media sosial bisa menyebabkan gangguan tidur [27]. Penelitian saat ini menemukan bahwa mayoritas responden remaja memiliki intensitas penggunaan media sosial yang tinggi dengan kualitas tidur yang buruk sebanyak 66 responden $(35,1 \%)$. Hal ini dapat disebabkan oleh penggunaan media sosial meningkatkan emosi dan kognitif remaja untuk lebih memusatkan perhatiannya (engaged) menelusuri akun sosial dan secara tidak langsung memperpanjang jam untuk memulai tidur. Seperti studi Levenson, Shensa, beberapa kemungkinan penyebab gangguan tidur, yaitu dampak media sosial yang menggantikan waktu tidur, peningkatan gairah psikososial saat mengakses media sosial, dan melambatnya ritme sirkadian akibat cahaya terang dari perangkat media sosial yang digunakan sebelum tidur.

Jika tidak ditangani, buruknya kualitas tidur pada remaja dapat mempengaruhi capaian akademik mereka. Hal ini didukung oleh penelitian Urrila, Artiges yang menyatakan bahwa akses media sosial oleh para remaja saat akhir pekan saja berkaitan dengan prestasi belajar buruk, yang diduga berhubungan dengan perubahan struktur otak remaja. Pada penelitian saat ini, intensitas penggunaan media sosial seperti Facebook, Instagram, dan Whatsapp dapat dikategorikan tinggi karena $88.8 \%$ remaja memiliki $>2$ akun media sosial aktif sehingga dapat menyita waktu produktif dan istirahat remaja. Selanjutnya, aktivitas tersebut dikhawatirkan dapat membentuk pola perilaku berisiko yang dapat berdampak pada kehidupan akademik remaja.

\section{SIMPULAN}

Ada hubungan yang signifikan antara intensitas penggunaan media sosial dengan kualitas tidur pada remaja. Penelitian ini menunjukkan bahwa penggunaan media sosial dengan intensitas yang lebih tinggi akan menyebabkan kualitas tidur semakin buruk. Oleh karena itu, remaja perlu mengontrol diri menggunakan media sosial agar tidak mengganggu jadwal tidur dan aktivitas penting lainnya. Saran untuk penelitian selanjutnya, yaitu dapat mengembangkan penelitian mengenai faktor lain yang dapat mempengaruhi kualitas tidur pada remaja dengan metode penelitian yang berbeda.

\section{UCAPAN TERIMA KASIH}

Peneliti mengucapkan terima kasih kepada responden remaja dan Fakultas Ilmu Kesehatan Universitas Muhammadiyah Tangerang yang telah mendukung penelitian ini.

\section{REFERENSI}

[1] Badan Perencanaan Pembangunan Nasional. Proyeksi Penduduk Indonesia 2010-2035. Jakarta; 2013.

[2] National Sleep Foundation. Adolescent Sleep Needs and Patterns. 2018 [Available from: https://www.sleepfoundation.org/teensand-sleep.

[3] Short MA, Gradisar M, Gill J, Camfferman D. Identifying adolescent sleep problems. PLoS One. 2013;8(9):e75301. 
[4] Nafiah N. Hubungan Durasi Penggunaan Media Sosial dengan Kualitas Tidur pada Remaja Kelas VIII Di Smp Muhammadiyah 1 Yogyakarta: Universitas' Aisyiyah Yogyakarta; 2019.

[5] Center for Disease Control and Prevention (CDC). Sleep in Middle and High School Student [Available from: https://www.cdc.gov/healthyschools/featur es/students-

sleep.htm\#: :text=The\%20American\%20Ac ademy\%20of\%20Sleep,10\%20hours\%20per $\% 2024 \% 20$ hours.

[6] Chaput J-P, Dutil C, Sampasa-Kanyinga H. Sleeping hours: what is the ideal number and how does age impact this? Nat Sci Sleep. 2018;10:421-30.

[7] Khusnal E. Hubungan Perilaku Penggunaan Gadget Dengan Kualitas Tidur Pada Anak Usia Remaja Di SMA Negeri 1 Srandakan Bantul: Universitas' Aisyiyah Yogyakarta; 2017.

[8] Bruce ES, Lunt L, McDonagh JE. Sleep in adolescents and young adults. Clin Med (Lond). 2017;17(5):424-8.

[9] Punkasaningtiyas R. Hubungan Penggunaan Media Sosial Dengan Kualitas Tidur, Kestabilan Emosi Dan Kecemasan Sosial Pada Remaja Di SMAN 20 Surabaya: Universitas Airlangga; 2018.

[10] Lombogia BJ, Kairupan BH, Dundu AE. Hubungan kecanduan internet dengan kualitas tidur pada siswa SMA Kristen 1 Tomohon. Jurnal Medik Dan Rehabilitasi. 2018;1(2).

[11] Azmi S, Erkadius E. Hubungan kualitas tidur dengan tekanan darah pada pelajar kelas 2 SMA Negeri 10 Padang. Jurnal Kesehatan Andalas. 2017;6(2):318-23.

[12] Urrila AS, Artiges E, Massicotte J, Miranda R, Vulser H, Bézivin-Frere P, et al. Sleep habits, academic performance, and the adolescent brain structure. Scientific reports. 2017;7:41678-.

[13] Gomes GC, Passos MHPD, Silva HA, Oliveira VMAd, Novaes WA, Pitangui ACR, et al. Sleep Quality And Its Association With Psychological Symptoms In Adolescent Athletes. Rev Paul Pediatr. 2017;35(3):31621.

[14] Dimitriou D, Le Cornu Knight F, Milton P. The Role of Environmental Factors on Sleep Patterns and School Performance in Adolescents. Front Psychol. 2015;6:1717-.

[15] Owens J. Insufficient Sleep in Adolescents and Young Adults: An Update on Causes and
Consequences. Pediatrics. 2014;134(3):e921e32.

[16] Asosiasi Penyelenggara Jasa Internet Indonesia. Infografis Penetrasi dan Perilaku Pengguna Internet Indonesia. 2017.

[17] Shimoga SV, Erlyana E, Rebello V. Associations of Social Media Use With Physical Activity and Sleep Adequacy Among Adolescents: CrossSectional Survey. J Med Internet Res. 2019;21(6):e14290.

[18] Aulia HF. Hubungan antara Intensitas Penggunaan Media Sosial dengan Kualitas Tidur pada Mahasiswa International Program of International Relation Universitas Muhammadiyah Yogyakarta Angkatan 2014 [Bachelor]2016.

[19] Kaimal D, Sajja RT, Sasangohar F. Investigating the Effects of Social Media Usage on Sleep Quality. Proceedings of the Human Factors and Ergonomics Society Annual Meeting. 2017;61(1):1327-30.

[20] Olufadi Y. Social networking time use scale (SONTUS): A new instrument for measuring the time spent on the social networking sites. Telematics and Informatics. 2016;33(2):45271.

[21] Buysse DJ, Reynolds CF, Monk TH, Berman SR, Kupfer DJ. The Pittsburgh sleep quality index: A new instrument for psychiatric practice and research. Psychiatry Research. 1989;28(2):193-213.

[22] Candra DA. Kesepian dan Intensitas Penggunaan Media Sosial Pada Mahasiswa [Skripsi Sarjana]: University of Muhammadiyah Malang; 2017.

[23] Dewi LP, Suesti S. Hubungan intensitas penggunaan situs jejaring sosial dengan insomnia pada remaja di sma muhammadiyah 7 yogyakarta [Skripsi Sarjana]: Universitas' Aisyiyah Yogyakarta; 2017.

[24] Laila YN. Korelasi Antara Kebutuhan Afiliasi dan Keterbukaan Diri dengan Intensitas Menggunakan Jejaring Sosial pada Siswa Kelas VIII SMP Negeri 15 Yogyakarta [Skripsi]. Yogyakarta: Universitas Negeri Yogyakarta; 2014.

[25] Burnette CB, Kwitowski MA, Mazzeo SE. "I don't need people to tell me I'm pretty on social media:" A qualitative study of social media and body image in early adolescent girls. Body Image. 2017;23:114-25.

[26] Woods HC, Scott H. \#Sleepyteens: Social media use in adolescence is associated with poor sleep quality, anxiety, depression and low self-esteem. J Adolesc. 2016;51:41-9. 
[27] Levenson JC, Shensa A, Sidani JE, Colditz JB,

young adults. Preventive Medicine. Primack BA. The association between social 2016;85:36-41.

media use and sleep disturbance among 